\title{
Tanda Tangan Elektronik pada Transaksi Jual Beli Online: Suatu Kajian Hukum Keamanan Data Konsumen di Indonesia
}

\author{
Hari Sutra Disemadi ${ }^{*}$, Denny Prasetyo ${ }^{2}$ \\ ${ }^{1,2}$ Fakultas Hukum, Universitas Internasional Batam, Indonesia \\ *correspondence email: hari@uib.ac.id, 1651009.denny@uib.edu
}

\begin{abstract}
Abstrak. Penelitian ini akan membahas serta mengkaji seberapa pentingnya kesiapan terhadap regulasi yang bersifat komprehensif yang berfungsi mengatur secara tegas tentang perlindungan data pribadi dalam menggunakan tanda tangan elektronik yang digunakan dalam transaksi jual-beli online. Penelitian ini merupakan penelitian hukum (legal research) disusun menggunakan metode penelitian hukum normatif. Penelitian ini menunjukan tanda tangan elektronik dalam transaksi jual beli online merupakan istilah hukum yang berasal dari tanda tangan digital yang berfungsi untuk autentifikasi dan verifikasi data pribadi seseorang yang membuatnya secara elektronik maupun online sebagai bentuk digital identitas penggunanya, serta sebagai bukti persetujuan dari suatu perjanjian pada transaksi online sebagai bentuk pecegahan terhadap tindak kejahatan siber. Tanda tangan elektronik perlu diperhatikan dimana pemerintah dapat memprioritaskan dalam mengesahkan regulasi ini agar dapat memberikan jaminan keamanan terhadap perlindungan data pribadi pada saat pemilik tanda tangan elektronik menggunakannya untuk melakukan verifikasi, dan validasi pada suatu kontrak perjanjian dalam transaksi online. Perlindungan yang dimaksud merupakan suatu aturan yang didalamnya diatur mengenai kedaulatan data, hak hak dan kewajiban para pihak, beserta sanksi pidana maupun perdata sehingga dapat mencegah penyalahgunaan data pribadi.
\end{abstract}

Kata kunci: Tanda Tangan Elektronik; Data Konsumen; Jual Beli Online

\begin{abstract}
This research will discuss and examine the importance of readiness for comprehensive regulations that function to strictly regulate the protection of personal data in using electronic signatures used in online buying and selling transactions. This research is legal research prepared using normative legal research methods. This research shows that the electronic signature in online buying and selling transactions is a legal term derived from a digital signature that functions to authenticate and verify a person's data that makes it electronically or online as a digital form of user identity, as well as proof of approval of an agreement on the transaction online as a form of prevention against cyber crime. Electronic signatures need to be considered where the government can prioritize ratifying this regulation to provide security guarantees for the protection of personal data when the owner of the electronic signature uses it to verify and validate an agreement contract in online transactions. The protection in question is a rule which regulates data sovereignty, rights, and obligations of the parties, along with criminal and civil sanctions to prevent misuse of personal data.
\end{abstract}

Keywords: Electronic Signature; Consumer Data; Online Buying and Selling

\section{PENDAHULUAN}

Perkembangan dunia industri bergerak sangat cepat dan perubahannya dapat dirasakan oleh semua orang, mulai dari Industri 1.0 yang masih menggunakan tenaga uap dan pompa air dalam proses Industrinya, pada Industri 2.0 yang dicetuskannya pabrik untuk memproduksi massal suatu produk dengan perkembangan yang sudah menggunakan mesin elektrik, pada Industri 3.0 perkembangannya sudah menggunakan elektronik, dan berbasis sistem teknologi informasi seperti robot yang dapat mengerjakan sesuatu dengan otomatis, dan sampai pada tahap Industri 4.0 dengan perkembangannya yang menggunakan cyber physical systems atau biasa disebut sebagai perpaduan antara mesin, yang dikembangkan melalui sistem komputerisasi, dijalankan berbasis online ${ }^{1}$.

Revolusi industri yang terjadi saat ini sangat berdampak dalam aktifitas sehari hari, salah satu hal kecilnya adalah perubahan yang terjadi pada pola konsumsi manusia ${ }^{2}$, dimana yang pada awalnya masih bersifat konvensional dengan pergi bertemu pedagang di tempat perbelanjaan, menuju ke pola non-konvensional seperti menggunakan platform belanja online yang dapat dipesan kapanpun dan dimanapun melalui aplikasi belanja online ${ }^{3}$. Selain revolusi ini, masa pandemi seperti saat ini mendorong para konsumen untuk berbelanja online ${ }^{4}$, serta membuka pandangan baru kepada masyarakat untuk melihat manfaat dari perkembangan industri dan teknologi secara jelas dan menjadikan

${ }^{1}$ Yati Nurhayati et al., "The Issue of Copyright Infringement in 4.0 Industrial Revolution: Indonesian Case," Jurnal Media Hukum 26, no. 2 (2019): 122-30, https://doi.org/10.18196/jmh.20190128. digitalisasi/.

2 Faspay, "Revolusi Industri 4.0: Era Digitalisasi," 2019, https://faspay.co.id/id/2019/07/09/revolusi-industri-4-0-era-

3 Masitoh Indriyani, "Perlindungan Privasi Dan Data Pribadi Konsumen Daring Pada Online Marketplace System," JUSTITIA JURNAL HUKUM 1, no. 2 (October 2017): 191-028, https://doi.org/10.30651/justitia.v1i2.1152.

${ }^{4}$ Meria Agustina, "Persaingan Usaha Tidak Sehat Antar Online Shop Dalam Kondisi Covid-19 Terhadap Kebijakan Yang Dikeluarkan Oleh Presiden,” Res Judicata 3, no. 1 (2020): 15-25, https://doi.org/http://dx.doi.org/10.29406/rj.v3i1.2059. 
kesempatan yang terjadi akibat masa pandemi yang melahirkan banyak Usaha Mikro, Kecil, Menengah selanjutnya disebut UMKM yang terjun dalam usaha online. Didapatkan data terhadap jumlah pelanggan $e$-commerce atau belanja online tercatat meningkat mencapai angka $38,8 \%$ selama masa pandemi ini ${ }^{5}$. Pandemi yang menyebabkan terjadinya krisis dunia pada saat ini berasal dari wabah Severe Acute Respiratory Syndrome Coronavirus 2 (SARS-Cov-2) atau yang sekarang dikenal sebagai COVID- $19^{6}$.

Hadirnya COVID-19 bermula dari laporan Negara China kepada organisasi kesehatan dunia atau yang biasa dikenal dengan WHO (World Health Organization). Virus COVID-19 ini dilaporkan pada tanggal 31 Desember 2019 ${ }^{7}$, dan berdasarkan laporan tersbut dampak dari COVID-19 menyebabkan pneumonia yang artinya adalah peradangan paru-paru yang disebabkan karena terjadinya infeksi yang berasal dari bakteri yang sama dengan flu ${ }^{8}$. Infeksi paruparu yang kronis ini berasal dari Kota Wuhan, Provinsi Hubei, China. Kasus COVID-19 yang pertama kali terjadi diluar dari negara china diketahui di negara Thailand pada tanggal 13 Januari 2020. Di benua Asia mulai banyak dilaporkan kasus serupa, bahwa meluas nya virus ini tersebar hingga wilayah timur tengah dan mulai bertambah sehingga tersebar ke banyak negara, dalam bulan yang sama terkonfirmasi laporan kasus serupa yang sampai pada benua Australia, tercatat sejak bulan Maret 2020 bahwa 65 negara sudah melaporkan adanya infeksi COVID-19 ${ }^{9}$.

Pandemi COVID-19 ini telah menembus berbagai aspek fundamental negara termasuk menyebabkan penurunan ekonomi, sehingga banyak negara termasuk Indonesia menerapkan kebijakan social distancing. Peran dari Industri 4.0 yang berbasis online pada masa pendemi saat ini dinilai sangat penting. Hingga sampai saat ini segala kebutuhan dapat dipenuhi hanya menggunakan gadget atau smartphone dimanapun, kapanpun tanpa harus pergi meninggalkan rumah, salah satu perkembangannya adalah transaksi jual beli secara online. Segala kemudahan yang terjadi akibat perkembangan teknologi sangat berdampak baik dalam lingkungan masyarakat, terkhusus pada kegiatan transaksi jual beli yang dapat dilakukan secara online. Namun, permasalahan yang muncul pada transaksi online adalah penipuan dan pencurian data konsuman. Masih banyak terdapat celah hukum yang dapat dimanfaatkan bagi para pelaku kriminal dalam dunia siber, terkhusus pada kegiatan transaksi jual beli online melalui platform belanja online yang tidak diketahui status hukumnya ${ }^{10}$. Konsumen yang tanpa mempertimbangkan risiko terhadap situs-situs belanja online yang tidak resmi berpotensi menyebabkan penyalahgunaan hak konsumen ${ }^{11}$, seperti ada kemungkinan barang yang sudah dibayarkan sesuai apa yang dipesan oleh konsumen tidak datang dan pihak penanggungjawab kabur; barang yang dipesan tidak sesuai dengan pesanan, juga sering terjadi dalam transaksi jual beli online, dua hal penyebab terjadinya hal tersebut berasal dari suatu kesengajaan dari pihak pertama selaku penjual, atau murni berdasarkan kelalaian penjual. Permasalahan terkait hak konsumen lainnya adalah pencurian data konsuman. Saat melakukan transaksi elektronik, sebagai konsumen harus tetap waspada karena beberapa dari situs jual beli online mewajibkan konsumen untuk mengisi data pribadi seperti data personal, dan identitas penting lainnya sebelum menggunakan layanan yang ada pada situs tersebut ${ }^{12}$.

Dikarenakan kemudahan untuk menggunakan internet, situs-situs transaksi jual beli online juga mulai bertambah dan berkembang pesat mengikuti kebutuhan masyarakat, terutama terhadap sistem validasi yang hanya menggunakan panel-panel seperti checklist, setuju, dan sebagainya. Tanpa adanya kontrak perjanjian jual beli online, maka perlu diwaspadai tentang penggunaan kontrak perjanjian tersebut apakah sudah sesuai dengan asas-asas perjanjian, perlindungan hukum bagi kedua belah pihak, dan keamanan data pribadi saat proses transaksi jual beli online. Dewasa ini proses validasi data konsumen via online dinilai masih diragukan, karena semakin banyak situs belanja online yang beredar maka semakin sulit membedakan antara yang berbentuk badan usaha resmi atau kepemilikan individu, hal ini berpotensi terjadinya resiko tindakan penipuan.

${ }^{5}$ Dewi Adhitya S. Koesno, "Jumlah Pelanggan E-Commerce Tercatat Meningkat 38,3\% Selama Pandemi," 2020.

6 Tommaso Lupia et al., "2019 Novel Coronavirus (2019-NCoV) Outbreak: A New Challenge," Journal of Global Antimicrobial Resistance 21 (2020): 22-27, https://doi.org/10.1016/j.jgar.2020.02.021.

${ }^{7}$ Ikhsan et al., "Upaya Perlindungan Anak Dalam Peradilan Pidana Di Era Pemberlakuan 'New Normal' Selama Pandemi COVID-19 Di Indonesia," Jurnal Ilmu Hukum 9, no. 2 (2020): 225-42, https://doi.org/dx.doi.org/10.30652/jih.v9i2.7933; Rindam Nasruddin and Islamul Haq, "Pembatasan Sosial Berskala Besar (PSBB) Dan Masyarakat Berpenghasilan Rendah," SALAM: Jurnal Sosial Dan Budaya Syar-I 7, no. 7 (May 2020): 639-48, https://doi.org/10.15408/sjsbs.v7i7.15569.

${ }^{8}$ Lupia et al., "2019 Novel Coronavirus (2019-NCoV) Outbreak: A New Challenge."

${ }^{9}$ Bima Baskara, "Rangkaian Peristiwa Pertama Covid-19," 2020, https://bebas.kompas.id/baca/riset/2020/04/18/rangkaianperistiwa-pertama-covid-19/.

10 Asri Wijayanti, Rizania Kharismasari, and Aditya Ayu Hakiki, "Perlindungan Hukum Bagi Pembeli Dalam Sengketa Jual Beli Online,” JUSTITIA JURNAL HUKUM 1, no. 1 (July 2017): 119-30, https://doi.org/10.30651/justitia.v1i1.596.

11 Aan Aswari, "Peran Ganda Administrator Sebagai Mediator Dalam Sengketa Transaksi Ponsel Bekas Secara Online," Jurnal Ilmiah Kebijakan Hukum 12, no. 3 (December 2018): 259-74, https://doi.org/10.30641/kebijakan.2018.V12.259-274.

12 Wawan Fransisco, "Peranan Hukum Terhadap Konsumen Jual Beli Online Di Indonesia," Ajudikasi: Jurnal Ilmu Hukum 3, no. 2 (2019): 197-210. 
Tanda tangan elektronik merupakan suatu inovasi dari perusahaan berbasis teknologi, salah satunya adalah PT. Privy Identitas Digital (Privy ID), sebagai penyedia dan penyelenggara tanda tangan elektronik yang berkekuatan hukum dan bersifat mengikat. Bentuk dari tanda tangan elektronik ini disebut sebagai "private key" atau kunci privat yang dibuat secara unik bagi individu yang mendaftarkannya, dan hanya diketahui dan dikuasai oleh pemilik tanda tangan elektronik tersebut, dimana fungsinya adalah untuk memvalidasi tanda tangan elektronik seseorang ${ }^{13}$. Berdasarkan paparan di atas, maka penelitian ini penting dilakukan agar dapat menambah wawasan kepada masyarakat, guna untuk menumbuhkan kesadaran masyarakat terhadap pentingnya perlindungan data pribadi yang dapat dimulai dari diri sendiri. Berdasarkan paparan tersebut maka permasalahan yang diangkat dalam penelitian ini adalah mempertanyakan kebijakan penggunaan tanda tangan elektronik pada transaksi online dan bagaimana asas-asas perlindungan hukum terhadap data pribadi konsumen pada transaksi jual beli online.

\section{METODE}

Penelitian yang diberi judul "Tanda Tangan Elektronik Pada Transaksi Jual Beli Online: Suatu Kajian Hukum Keamanan Data Konsumen Di Indonesia" menggunakan metode penelitian hukum normatif. Dalam metode penelitain hukum normatif ini menggunakan pendekatan perundang-udanganan dan pendekatan konseptual. Data yang dianalisis secara deskriptif-kualitatif dalam penelitian ini adalah data sekunder yang di peroleh secara tidak lansung. Data tersebut terbagi atas bahan hukum primer, sekunder, tersier yang memiliki keterkaitan dengan perlindungan data pribadi konsumen, dan hubungannya dengan pencegahan risiko transaksi online ${ }^{14}$. Proses dalam pengumpulan bahan hukum dilakukan berdasarkan mempelajari peraturan perundang-undangan, buku-buku, jurnal, pendapat para pakar ataupun ahli, dan hasil penelitian lain yang terkait dengan penelitian ini. Pendekatan yang dilakukan dalam pengimplementasian data sekunder tersebut menggunakan metode deduktif dimana penelitian ini mencoba mencari solusi dari isu hukum yang terjadi ${ }^{15}$. Dengan cara menggabungkan antara premis utama yaitu mengenai keamanan data pribadi konsumen dengan menggunakan tanda tangan elektronik dalam proses transaksi jual beli online, dan premis pendamping yaitu hukum perlindungan konsumen. Perpaduan antara kedua premis tersebut ditujukan untuk menemukan kesimpulan dari permasalahan yang ada.

\section{HASIL DAN PEMBAHASAN}

\section{Kebijakan Penggunaan Tanda Tangan Elektronik Pada Transaksi Online}

Pada Kitab Undang-Undang Hukum Perdata Indonesia (KUHPer) dimulai dari Pasal 1457 sampai dengan Pasal 1540 mengatur tentang suatu perjanjian jual beli. Perjanjian jual beli memiliki istilah yang berasal dari kata "contract of sale". Pada Pasal 1457 KUHPer dijelaskan bahwa "perjanjian, dengan mana pihak yang satu mengikatkan dirinya untuk menyerahkan suatu kebendaan, dan pihak yang lain untuk membayar harga yang telah dijanjikan". Penjelasan Pasal 1457 KUHPer, dijelaskan mengenai perjanjian jual beli, dengan artian sebagai "persetujuan antara penjual dan pembeli tentang objek atau barang yang diperjanjikan dengan pembeli yang memenuhi kewajibannya untuk membayar harga yang disepakati kepada penjual, dan pembeli dapat menerima hak nya untuk menerima suatu objek atau barang yang telah diperjanjikan". Kemudian, penjelasan Pasal 1320 KUHPer, juga menyebutkan sebagai salah satu syarat sah perjanjian, dijelaskan bahwa jual beli dianggap telah terjadi setelah kedua belah pihak mencapai kesepakatan tentang harga suatu objek atau barang, meskipun kewajiban masing-masing pihak belum terpenuhi saat itu. Karena, faktor utama terjadinya syarat sah perjanjian jual beli terhadap sebuah barang adalah apabila telah terjadi kesepakatan sederhana antara kedua belah pihak.

Dewasa ini jual beli tidak hanya dilakukan secara konvensional melainkan secara non-konvensional yaitu jual beli dengan menggunakan elektronik (online) ${ }^{16}$. Suatu proses pembelian barang atau jasa melalui internet, atau layanan jual beli secara online tanpa harus bertatap muka dengan penjual atau pihak pembeli secara langsung disebut "online shopping" atau belanja online via internet ${ }^{17}$. Namun, tidak semua situs belanja online, ataupun platform transaksi elektronik lainnya, mengaplikasikan tentang kontrak perjanjian jual beli secara online. Para pelaku jual beli online yang tidak mengaplikasikan tentang kontrak jual beli online tersebut dapat diistilahkan dengan "silent onsent" atau biasa disebut dengan perjanjian diam-diam yaitu tanpa adanya persetujuan tertulis menggunakan tanda tangan.

\footnotetext{
13 Sigar Aji Poerana, "Cara Kerja Tanda Tangan Elektronik,” 2020.

${ }^{14}$ Suteki and Galang Taufani, Metodologi Penelitian Hukum (Filasafat, Teori Dan Praktik) (Depok: Rajagrafindo Persada,

15 Junimart Girsang et al., "Pertanggungjawaban Hukum Perusahaan Asuransi Terhadap Penolakan Klaim Atas Kehilangan Kendaraan Bermotor," Jurnal Justitia 7, no. 4 (2020): 819-29, https://doi.org/dx.doi.org/10.31604/justitia.v7i4.819-829.

${ }^{16}$ Fransisco, "Peranan Hukum Terhadap Konsumen Jual Beli Online Di Indonesia."

${ }^{17}$ Wijayanti, Kharismasari, and Hakiki, "Perlindungan Hukum Bagi Pembeli Dalam Sengketa Jual Beli Online."
} 2018). 
Namun, dalam aspek hukum dijelaskan bahwa perjanjian diam-diam tersebut dapat dianggap sebagai keabsahan dalam suatu perikatan ${ }^{18}$.

Istilah "silent consent" dalam hukum perdata merupakan suatu kehendak dari salah satu pihak yang ditujukan kepada pihak lainnya, dimana tidak ada gerakan penolakan secara tegas terhadap suatu perikatan maupun tindakan hukum dan menyebabkan pihak yang bersangkutan dianggap telah menyutujui kehendak dari pihak lainnya ${ }^{19}$. Berkaca pada Pasal 1347 KUHPer, maka "hal-hal yang selalu diperjanjikan menurut kebiasaan dianggap secara diamdiam tetap dikategorikan kedalam perjanjian, meskipun tidak dengan tegas dinyatakan. Oleh karena dianggap sebagai bagian perjanjian maka hal yang menurut kebiasaan selalu diperjanjikan itu dapat menyingkirkan suatu pasal undangundang yang merupakan hukum pelengkap". Dikarenakan terjadinya persetujuan diam-diam tersebut, maka Asas konsensualisme yang dijelaskan Pasal 1320 KUHPer mulai berlaku secara otomatis. Sebagaimana diketahui bahwa, segala perjanjian yang terjadi di lingkungan masyarakat bersifat konsensuil, para pihak dianggap telah terikat oleh suatu perjanjian ketika telah mencapai kata sepakat yang dianggap sah dan mengikat apabila tercapainya kesepakatan, tanpa perlu formalitas. Dari uraian diatas dijelaskan masih banyak celah tindakan hukum yang dapat berdampak pada masyarakat yang masih awam terhadap perkembangan hukum dan hubungannya dengan perkembangan teknologi dalam transaksi jual beli online. Maka dari itu, perlu adanya tanda tangan elektronik dalam mengesahkan perjanjian jual beli secara online. Peran tanda tangan elektronik sangat penting selain untuk menjaga data pribadi konsumen, juga untuk mengurangi kejahatan dan penyalahgunaan dalam melakukan suatu kontrak maupun perjanjian dalam transaksi elektronik ${ }^{20}$.

Tanda tangan yang dilakukan secara online, terdiri dari 2 jenis yaitu tanda tangan elektronik dan tanda tangan digital. Secara istilah kedua jenis tanda tangan yang dilakukan secara online tersebut memiliki perbedaan dimana tanda tangan elektronik merupakan suatu istilah hukum yang dijelaskan pada peraturan perundang-undangan yang ada di Indonesia ${ }^{21}$. Sedangakan tanda tangan digital merupakan suatu istilah yang dijelaskan sebagai faktor penggerak, proses pelaksanaan pada metode yang digunakan tanda tanga elektronik yang menggunakan metode kriptografi asimetris degan platform yang disebut dengan "privat key" atau kunci privat ${ }^{22}$.

Secara teknis, penjelasan mengenai tanda tangan elektronik merupakan suatu dokumen elektronik yang ditandatangani secara digital, melalui proses enkripsi, dengan menggunakan kunci privat yang dimiliki individu yang membuat Tanda Tangan Digital tersebut, melalui plaintext berupa suatu teks yang berisikan informasi terkait masukan dari algoritme enkripsi yang bertujuan untuk membaca teks bersandi yang telah melalui proses hashing, atau yang biasa disebut suatu proses untuk memastikan integritas ataupun keutuhan informasi yang tersimpan seperti proses autentifikasi ${ }^{23}$.

Menurut regulasi yang dijelaskan secara umum terdapat dalam Pasal 1 Undang-Undang Nomor 19 Tahun 2016 tentang Informasi dan Transaksi Elektronik (UU ITE), mengenai penyelenggara tanda tangan digital merupakan suatu badan hukum yang berkedudukan sebagai pihak yang dapat dipercaya, dalam memberikan, serta meng audit sertifikasi elektronik yang diterbitkan. Dalam implementasinya, pihak penyelenggara sertifikasi elektronik memerlukan suatu bentuk pasangan kunci dan sertifikat elektronik yang diterbitkan oleh Penyelenggara Sertifikat Elektronik/ Certification Authority disingkat menjadi PSrE/CA. Penjelasan tersebut sudah diatur secara umum di dalam UU ITE, dan secara spesifik diatur dalam Peraturan Pemerintah No. 11 Tahun 2018 tentang Penyelenggara Sertifikasi Elektronik (PP PSrE). Pengertian Sertifikat Elektronik merupakan suatu sertifikat yang diubah dalam bentuk digital yang memuat Tanda tangan elektronik yang berisikan identitas pemilik Tanda tangan elektronik yang menunjukkan bahwa seorang pemilik tanda tangan elektronik memiliki status sebagai subjek hukum dari penyelenggara sertifikasi elektronik.

Penjelasan sederhana mengenai tugas dari pihak penyedia/penyelenggara sertifikat elektronik pada Pasal 14 UU ITE, yaitu pihak penyedia/ penyelenggara sertifikat elektronik berkewajiban untuk memberikan informasi akurat, jelas, dan pasti kepada pengguna jasa sertifikat elektronik, antara lain "penggunaan metode dalam mengidentifikasi penanda tangan; hal yang digunakan untuk dapat mengetahui data pribadi pemilik tanda tangan elektronik; hal yang digunakan untuk dapat menunjukkan keberlakuan dan keamanan tanda tangan elektronik". Hal tersebut berlaku pula bagi penyelenggara sertifikat elektronik untuk memberitahukan kewenangannya. Penjelasan mengenai kewajiban

${ }^{18}$ Markhmah Isnaini, “Keabsahan Perjanjian Diam-Diam Dalam Perjanjian Distributor (Studi Putusan Mahkamah Agung Nomor 2178K/PDT/2008 Antara PT Dwi Damai Melawan PT Philips Indonesia),” Jurnal Privat Law 8, no. 1 (2020): 104-10.

${ }^{19}$ Isnaini.

${ }^{20}$ Poerana, "Cara Kerja Tanda Tangan Elektronik."

21 Husnul Hudzaifah, "Keabsahan Tanda Tangan Elektronik Dalam Pembuktian Hukum Acara Perdata Indonesia," Katalogis 3, no. 5 (2015): 194-204.

22 Poerana, "Cara Kerja Tanda Tangan Elektronik."

23 Thalis Noor Cahyadi, “Apek Hukum Pemamfaatan Digital Signature Dalam Meningkatkan Efisiensi, Akses Dan Kualitas Fintech Syariah,” Rechtsvinding 9, no. 2 (2020): 219-36. 
antara calon pemilik dan pihak penyelenggara yang tertera pada Pasal 60 Peraturan Pemerintah Nomor 82 Tahun 2012 tentang Penyelenggaraan Sistem dan Transaksi Elektronik, adalah "pemeriksaan calon pemilik dan/ atau pemegang sertifikat elektronik; mnerbitkan sertifikat elektronik; memperpanjang masa aktif sertifikat elektronik; memblokir dan mencabut sertifikat elektronik; validasi sertifikat elektronik; dan membuat daftar sertifikat elektronik yang aktif dan non-aktif".

Proteksi terhadap data pribadi konsumen transaksi online melalui tanda tangan elektronik di Indonesia di atur dalam UU ITE mengenai definisinya, yang tercantum dalam Pasal 1 angka 12 UU ITE, dijelaskan bahwa "tanda tangan elektronik adalah tanda tangan yang terdiri atas informasi elektronik yang dilekatkan, terasosiasi atau terkait dengan informasi elektronik lainnya yang digunakan sebagai alat verifikasi dan autentikasi”. Berdasarkan UU ITE, sebagai legalitas tanda tangan elektronik secara online merupakan suatu data yang menyimpan informasi elektronik bagi pengguna yang bersifat melekat, terasosiasi, serta saling terhubung dengan informasi elektronik lainnya ${ }^{24}$. Tanda tangan digital merupakan suatu tanda tangan elektronik yang sudah diverifikasi, sehingga tanda tangan elektronik berfungsi sebagai alat yang menjamin keaslian data dari pengguna, untuk memverifikasi dan autentifikasi, serta validasi dari identitas penandatangan yang digunakan pada kebutuhan pengisian dokumen secara online. Sehingga penggunaan tanda tangan digital hanya dapat dilakukan menggunakan sertifikat elektronik yang dikeluarkan oleh pihak penyedia/ penyelenggara sertifikasi elektronik yang telah diakui Kementrian Komunikasi dan Informatika Republik Indonesia, disingkat menjadi KEMENKOMINFO RI.

Dijelaskan pada Pasal 11 ayat (1) UU ITE, "syarat sah tanda tangan elektronik yang memiliki kekuatan hukum, antara lain: "1) data pembuatan tanda tangan elektronik terkait hanya kepada penandatangan;2) data pembuatan tanda tangan elektronik pada saat proses penandatanganan hanya "berada "dalam kuasa penandatangan; 3) segala perubahan terhadap tanda tangan eelektronik yang terjadi setelah waktu penandatangganan dapat diketahui; 4) segala perubahan terhadap iinformasii elektronik yang terakit dengan tanda tangan elektronik tersebut setelah waktu penandatangganan dapat diketahui; 5) terdapat cara tertentu yang dapat diapakai untuk mengindetifikasi siapa penandatangganannya; dan 6) terdapat cara tertentu untuk menunjukkan bahwa penadatangganan telah memberikan persetujuan terhadap informasi elektronik yang terkait".

Terdapat kelemahan perjanjian yang dilakukan pada transaksi online, yaitu dengan menyertakan data pribadi yang dapat diakses dengan mudah secara online jika tanpa adanya proteksi data dalam dunia maya. Maka perlu adanya proteksi terhadap data pribadi konsumen transaksi online melalui tanda tangan elektronik yang di atur dalam UU ITE. Kemudian, berkaca pada Pasal 60 ayat (2) huruf a, dan ayat (3), PP Nomor 82 Tahun 2012, bahwa tanda tangan elektronik tersertifikasi, wajib memenuhi persyaratan, yaitu "memenuhi keabsahan kekuatan hukum dan akibat hukum tanda tangan elektronik sebagaimana dimaksud dalam Pasal 59 ayat (3) PP Nomor 82 Tahun 2012; menggunakan sertifikat elektronik yang dibuat oleh jasa penyelenggara sertifikasi elektronik Indonesia; dan dibuat dengan menggunakan perangkat pembuat tanda tangan elektronik tersertifikasi”. Mengenai tanda tangan elektronik yang dianggap tidak valid diatur lebih lanjut pada Pasal 60 ayat (2), huruf b dan ayat (4), PP Nomor 82 Tahun 2012 yang menegaskan mengenai tanda tangan elektronik yang tidak tersertifikasi yaitu suatu tanda tangan online yang dibuat tanpa menggunakan jasa penyelenggara sertifikasi elektronik".

Tanda tangan elektronik berfungsi sebagai alat autentifikasi dan verivikasi dari data diri/ identitas penanda tangan, dan kepastian dan keaslian data dari informasi elektronik. Penjelasan terkait merupakan penjelasan sederhana dari Pasal 60 ayat (1), PP No. 82 Tahun 2012. Suatu tanda tangan elektronik, memiliki kekuatan hukum dan akibat hukum yang sah, selama terpenuhinya persyaratan, yang tercantum pada Pasal 53 ayat (2) huruf a, PP No. 82 Tahun 2012 antara lain "data yang dibuat pemilik tanda tangan elektronik terkait hanya milik penanda tangan; data penanda tangan hanya milik kuasa penanda tangan, segala perubahan data yang diubah oleh pemilik data dapat diketahui, segala perubahan terhadap informasi elektronik yang terkait dengan tanda tangan elektronik setelah waktu penanda tanganan dapat diketahui, terdapat cara khusus untuk mengetahui dan mengidentifikasi pemilik tanda tangan, serta terdapat cara khusus untuk mengidentifikasi penanda tangan bahwa telah memberikan persetujuan terhadap informasi elektronik yang terkait".

Uraian diatas merupakan persyaratan minimum yang wajib dipenuhi pada setiap tanda tangan elektronik, penjelasan tersebut tercantum pada alinea kedua Kedua penjelasan Pasal 11 ayat (1) UU ITE, dimana berfungsi sebagai pengembangan metode, teknik, serta proses dalam pembuatan tanda tangan elektronik. Tanda tangan elektronik memiliki suatu kedudukan yang sama dengan tanda tangan konvensional dan memiliki kekuatan hukum dan akibat hukum yang sama. Pengertian tersebut dijelaskan pada alinea pertama Pasal 11 ayat (1) UU ITE bagian penjelasan bahwa "undang-undang ini memberikan pengakuan secara tegas bahwa meskipun hanya merupakan suatu kode, tanda tangan elektronik memiliki kedudukan yang sama dengan tanda tangan manual pada umumnya yang memiliki kekuatan hukum dan akibat hukum. persyaratan sebagaimana dimaksud dalam pasal ini merupakan persyaratan minimum yang harus dipenuhi dalam setiap tanda tangan elektronik. Ketentuan ini membuka kesempatan

${ }^{24}$ Sigar Aji Poerana, “Legalitas Penggunaan Tanda Tangan Elektronik Oleh Notaris,” 2020. 
seluasluasnya kepada siapa pun untuk mengembangkan metode, teknik, atau proses pembuatan tanda tangan elektronik".

\section{Perlindungan Hukum Terhadap Data Pribadi Konsumen pada Transaksi Jual Beli Online}

Landasan hukum pada perjanjian jual beli yang dilakukan secara online memiliki prinsip yang tidak berbeda dengan perjanjian jual beli konvensional. Pada perjanjian jual beli secara online atau transaksi elektronik juga tetap menggunakan asas hukum dalam suatu perjanjian, antara lain ${ }^{25}$ :

\section{Asas Kebebasan Berkontrak}

Setiap orang maupun badan hukum, bebas melakukan perbuatan hukum dalam bentuk sebuah kontrak dengan orang sesama orang, maupun badan hukum sesama badan hukum. pengertian berikut merupakan penjelasan sederhana definisi dari asas kebebasan berkontrak. Asas kebebasan berkontrak ditegaskan kembali dalam KUHPer Pasal 1338 ayat (1), bahwa "semua perjanjian yang dibuat secara sah berlaku sebagai undang-undang bagi mereka yang membuatnya". Berartinya asas kebebasan berkontrak apabila dalam pelaksanaannya mengedepankan kaidah-kaidah serta norma hukum yang berjalan di masyarakat ${ }^{26}$. Diantaranya adalah "dimana setiap orang bebas membuat dan/ atau tidak membuat perjanjian; Setiap orang bebas menentukan siapa saja yang ingin diajak untuk membuat perjanjian; Setiap orang bebas merumuskan format isi perjanjian yang akan dibuat; Setiap orang bebas memutuskan bentukbentuk perjanjian yang akan bereka buat".

\section{Asas Kesepakatan/ Konsensualisme}

Terwujudnya suatu kontrak perjanjian asas konsensualisme merupakan suatu bahan utama dalam terjadinya suatu perikatan. Karena asas konsensualisme dalam KUHPer Pasal 1320 merupakan pelaksanaan persyaratan subjektif suatu perjanjian. Oleh karenanya perjanjian yang dibuat harus berdasarkan kesepakatan dari kedua belah pihak yang melakukan perikatan ${ }^{27}$. Asas kesepakatan/ konsensualisme secara sederhana dijelaskan bahwa didalam suatu perikatan terkandung suatu persetujuan yang dapat dilakukan kedua belah pihak, baik secara lisan maupun tulisan yang berbentuk suatu akta sebagai dasar dari keinginan dari masing-masing pihak ${ }^{28}$.

\section{Asas Kepastian Hukum/ Pacta Sunt Servanda}

Segala bentuk perjanjian yang dibuat oleh masing-masing pihak, wajib memberikan kepastian hukum bagi pembentuk perikatan tersebut. Oleh karenanya dalam pelaksanaan suatu perjanjian yang telah dibuat bersama wajib dilaksanakan dengan sukarela dan tanpa ada paksaan bagi para pembuat perjanjian. Secara sederhana diatur dalam KUHPer Pasal 1338, dimana "semua perjanjian yang dibuat secara sah berlaku sebagai undang-undang bagi mereka yang membuatnya", yang berfungsi sebagai landasan hukum bagi para pihak yang membuat suatu perikatan yang pada dasarnya tidak dapat dibatalkan maupun ditarik secara sepihak, kecuali dimungkinkan lain dalam perjanjian yang dibuat bersama.

\section{Asas Itikad Baik/ Goodwill}

Dalam membentuk suatu perikatan diperlukan Itikad baik bagi para pihak yang membentuk suatu perikatan, dan menjadi hal utama dalam terjadinya suatu perjanjian, yang menumbuhkan tanggungjawab immaterial bagi para pihak pada asas ini. Dalam pelaksanaanya, itikad baik mengandung dua (2) syarat pokok, antara lain ${ }^{29}:$ 1) Syarat bbjektif, persyaratan yang dibuat tanpa mengedepankan norma social yang akan menyalahi itikad baik; dan 2) Syarat subjektif, persyaratan yang dibuat berkaitan dengan perasaan para pihak, serta sifat pribadi para pihak.

\section{Asas Kepribadian/Individualisme}

Asas kepribadian/ Individualisme memiliki maksud suatu perjanjian yang dibuat berdasarkan usaha seseorang ditujukan untuk dirinya sendiri tanpa ada campurtangan pihak lain, kecuali dikatakan lain dalam undang-undang. Membentuk suatu perjanjian, diperlukan beberapa asas-asas yang telah disebutkan diatas sebagai landasan utama untuk dimulainya suatu perikatan oleh para pihak. Legalitas dalam perjanjian transaksi online sama seperti perjanjian konvensional, dan terkait dengan KUHPer Pasal 1320, dimana suatu perjanjian yang dibuat secara online memiliki

${ }^{25}$ Salim H.S, Hukum Kontrak: Teori Dan Teknik Penyusunan (Yogyakarta: Sinar Grafika, 2003).

${ }^{26}$ Salim H.S.

${ }^{27}$ Salim H.S.

${ }^{28}$ Hari Sutra Disemadi, Paramita Prananingtyas, and Ratna Kumala Sari, "Legal Regulation and Protections for the Parties in the Franchise Business Agreements in Indonesia," Hang Tuah Law Journal 3, no. 3 (2020): 202-9, https://doi.org/doi.org/10.30649/htlj.v3i2.151.

${ }^{29}$ Handri Rahardjo, Hukum Perjanjin Di Indonesia (Jakarta: Pustaka Yustisia, 2009). 
kesamaan dalam kekuatan hukum pada suatu perikatan. Pasal 26 ayat (1), dalam UU ITE menjelaskan bahwa "Perlindungan data pribadi merupakan bagian dari privacy rights atau hak pribadi setiap individu mengandung 3 hal, antara lain: 1) Hak untuk menikmati kehidupan pribadi dan bebas dari segala macam gangguan; 2) Hak untuk dapat berkomunikasi dengan orang lain tanpa tindakan memata-matai; dan 3) Hak untuk mengawasi akses informasi tentang kehidupan pribadi dan data seseorang”.

Dapat diketahui bahwa di Indonesia belum mengatur secara khusus dan spesifik mengenai perlindungan data pribadi, jika dilihat secara aturan komprehensif mengenai perlindangan data pribadi di Indonesia sudah diatur secara sectoral dan partial dimana masing masing dari aturan tersebut tersebar menjadi 31 peraturan perundang-undangan. Antara lain Undang-Undang Hak Asasi Manusia, Undang-Undang Informasi dan Transaksi Elektronik, UndangUndang Administrasi Kependudukan, Undang-Undang Perbankan, Undang-Undang Kesehatan, Undang-Undang Perlindungan Konsumen, Undang-Undang Keterbukaan Informasi Publik, serta Undang-Undang Telekomunikasi. Meskipun dari uraian diatas belum diatur secara komrehensif, namun sudah dapat menjadi acuan ketika terjadinya tindakan hukum yang menggunakan data pribadi seseorang tanpa mendapatkan izin dari pemilik data pribadi, maka orang yang haknya dilanggar dapat mengajukan gugatan atas kerugian yang ditimbulkan.

Bentuk dari perlindungan konsumen jual beli online juga diatur pada Pasal 4 Undang-Undang Nomor 8 Tahun 1999 tentang Perlindungan Konsumen (UU Perlindungan Konseumen). UU Perlindungan Konsumen ini mengatur beberapa hak bagi konsumen yaitu "hak konsumen antara lain, merupakan hak atas kenyamanan, keamanan, dan keselamatan dalam mengkonsumsi barang dan/ atau jasa"; "hak untuk memilih barang dan/ atau jasa serta mendapatkan barang dan/ atau jasa tersebut sesuai dengan nilai tukar dan kondisi serta jaminan yang dijanjikan"; "hak atas informasi yang benar, jelas, dan jujur mengenai kondisi dan jaminan barang dan/ atau jasa"; "hak untuk didengar pendapat dan keluhannya atas barang dan/ atau jasa yang digunakan"; "hak untuk mendapatkan advokasi, perlindungan, dan upaya penyelesaian sengketa perlindungan konsumen secara patut; Hak untuk mendapat pembinaan dan pendidikan konsumen"; "hak untuk diperlakukan atau dilayani secara benar dan jujur serta tidak diskriminatif"; "hak untuk mendapatkan kompensasi, ganti rugi dan/ atau penggantian, apabila barang dan/ atau jasaa yang diterimaa tidak sesuaii dengan perjanjian atau tidak sebagaimana mestinya"; "hak-hak yang diatur dalam ketentuan peraturan perundang-undangan lainnya". Selanjutnya, apabila masyarakat selaku konsumen mengalami pelanggaran hak yang menimbulkan kerugian upaya perlindungan hukumnya dijelaskan dalam Pasal 4 huruf (h) UU Perlindungan Konsumen, disebutkan "berhak mendapatkan kompensasi, ganti kerugian dan/ atau penggantian apabila barang dan/ atau jasa yang diterima tidak sesuai dengan perjanjian atau tidak sebagaimana mestinya".

\section{SIMPULAN}

Dalam suatu perjanjian, transaksi online maupun persetujuan yang dilakukan secara online diperlukan tanda tangan elektronik. Tanda tangan elektronik merupakan istilah hukum yang berasal dari tanda tangan digital yang berfungsi untuk autentifikasi dan verifikasi data pribadi seseorang yang membuatnya secara elektronik maupun online sebagai bentuk digital identitas penggunanya, serta sebagai bukti persetujuan dari suatu perjanjian pada transaksi online sebagai bentuk pecegahan terhadap tindak kejahatan siber, dimana kepemilikan data atas tanda tangan elektronik diberikan oleh suatu badan hukum yang berkedudukan sebagai pihak penyelenggara tanda tangan elektronik yang diawasi langsung oleh Kementrian Komunikasi dan Informasi, dan memiliki kewajiban untuk menjaga kerahasiaan data pribadi pengguna jasa, dengan memberikan suatu bentuk sertifikat elektronik beserta privat key atau kunci pribadi sebagai kode unik dalam bentuk digital. Suatu tanda tangan elektronik dapat dikatakan sah ketika ketentuan sebagaimana dijelaskan dalam Pasal 11 UU Nomor 11 Tahun 2008 tentang Informasi dan Transaksi Elektronik, dan Pasal 59 PP Nomor 82 Tahun 2012 tentang Penyelenggaraan Sistem Transaksi Elektronik tersebut terpenuhi, dan menjadikan segala transaksi elektronik yang dilakukan menggunakan tanda tangan digital/ tanda tangan elektronik memiliki akibat hukum maupun kekuatan hukum yang sah sama seperti tanda tangan yang dilakukan secara konvensional. Meskipun tanda tangan elektronik memiliki akibat hukum maupun kekuatan hukum yang sah, sebagai pihak pengguna jasa tanda tangan elektronik juga tetap harus memperhatikan keamanan data pribadi pengguna, agar dalam kondisi tidak adanya regulasi yang mengatur tentang Perlindungan Data Pribadi secara khusus, agar masyarakat memiliki kebutuhannya pada perbuatan hukum yang dilakukan di dunia digital dengan menggunakan cara alternatif untuk keamanan dirinya menggunakan tanda tangan elektronik tetap dapat melaksanakan aktifitasnya secara normal.

Dikarenakan di Indonesia saat ini hanya memiliki satu Peraturan Menteri Komunikasi dan Informatika Nomor 20 Tahun 2016 tentang Perlindungan Data Pribadi, maka pemerintah diharapkan dapat melahirkan serta mengesahkan suatu produk hukum berupa undang-undang terkait perlindungan data pribadi sebagai prioritas, dimana peningkatan suatu perbuatan hukum dalam dunia digital merupakan suatu fakta disaat pandemi sedang berlangsung, yang bertujuan agar dapat mencegah terjadinya tindak kejahatan siber, hingga mengurangi persentasi terjadinya kejahatan siber di Indonesia seperti kerugian materil maupun non-materil, sehingga masyarakat merasa aman akan terciptanya kondisi yang stabil baik di dunia konvensional maupun digital dengan memperhatikan kesejahteraan, keadilan, bagi masyarakat. 
Hari Sutra Disemadi dan Denny Prasetyo, Tanda Tangan Elektronik pada Transaksi Jual Beli Online: Suatu Kajian Hukum

\section{DAFTAR PUSTAKA}

Agustina, Meria. "Persaingan Usaha Tidak Sehat Antar Online Shop Dalam Kondisi Covid-19 Terhadap Kebijakan Yang Dikeluarkan Oleh Presiden." Res Judicata 3, no. $1 \quad$ (2020): 15-25. https://doi.org/http://dx.doi.org/10.29406/rj.v3i1.2059.

Aswari, Aan. "Peran Ganda Administrator Sebagai Mediator Dalam Sengketa Transaksi Ponsel Bekas Secara Online." Jurnal Ilmiah Kebijakan Hukum 12, no. 3 (December 2018 ): $259-74$. https://doi.org/10.30641/kebijakan.2018.V12.259-274.

Baskara, Bima. "Rangkaian Peristiwa Pertama Covid-19," https://bebas.kompas.id/baca/riset/2020/04/18/rangkaian-peristiwa-pertama-covid-19/.

Cahyadi, Thalis Noor. "Apek Hukum Pemamfaatan Digital Signature Dalam Meningkatkan Efisiensi, Akses Dan Kualitas Fintech Syariah.” Rechtsvinding 9, no. 2 (2020): 219-36.

Disemadi, Hari Sutra, Paramita Prananingtyas, and Ratna Kumala Sari. "Legal Regulation and Protections for the Parties in the Franchise Business Agreements in Indonesia." Hang Tuah Law Journal 3, no. 3 (2020): $202-9$. https://doi.org/doi.org/10.30649/htlj.v3i2.151.

Faspay. "Revolusi Industri 4.0: Era Digitalisasi," 2019. https://faspay.co.id/id/2019/07/09/revolusi-industri-4-0-eradigitalisasi/.

Fransisco, Wawan. "Peranan Hukum Terhadap Konsumen Jual Beli Online Di Indonesia." Ajudikasi: Jurnal Ilmu Hukum 3, no. 2 (2019): 197-210.

Girsang, Junimart, Lu Sudirman, Febri Jaya, and Denygianto Halim. "Pertanggungjawaban Hukum Perusahaan Asuransi Terhadap Penolakan Klaim Atas Kehilangan Kendaraan Bermotor." Jurnal Justitia 7, no. 4 (2020): 819-29. https://doi.org/dx.doi.org/10.31604/justitia.v7i4.819-829.

Hudzaifah, Husnul. "Keabsahan Tanda Tangan Elektronik Dalam Pembuktian Hukum Acara Perdata Indonesia." Katalogis 3, no. 5 (2015): 194-204.

Ikhsan, Hari Sutra Disemadi, Syukri Kurniawan, and Pujiyono. "Upaya Perlindungan Anak Dalam Peradilan Pidana Di Era Pemberlakuan 'New Normal' Selama Pandemi COVID-19 Di Indonesia.” Jurnal Ilmu Hukum 9, no. 2 (2020): 225-42. https://doi.org/dx.doi.org/10.30652/jih.v9i2.7933.

Indriyani, Masitoh. "Perlindungan Privasi Dan Data Pribadi Konsumen Daring Pada Online Marketplace System." JUSTITIA JURNAL HUKUM 1, no. 2 (October 2017): 191-028. https://doi.org/10.30651/justitia.v1i2.1152.

Isnaini, Markhmah. "Keabsahan Perjanjian Diam-Diam Dalam Perjanjian Distributor (Studi Putusan Mahkamah Agung Nomor 2178K/PDT/2008 Antara PT Dwi Damai Melawan PT Philips Indonesia).” Jurnal Privat Law 8, no. 1 (2020): 104-10.

Koesno, Dewi Adhitya S. "Jumlah Pelanggan E-Commerce Tercatat Meningkat 38,3\% Selama Pandemi," 2020.

Lupia, Tommaso, Silvia Scabini, Simone Mornese Pinna, Giovanni Di Perri, Francesco Giuseppe De Rosa, and Silvia Corcione. "2019 Novel Coronavirus (2019-NCoV) Outbreak: A New Challenge." Journal of Global Antimicrobial Resistance 21 (2020): 22-27. https://doi.org/10.1016/j.jgar.2020.02.021.

Nasruddin, Rindam, and Islamul Haq. "Pembatasan Sosial Berskala Besar (PSBB) Dan Masyarakat Berpenghasilan Rendah." SALAM: Jurnal Sosial Dan Budaya Syar-I 7, no. 7 (May 2020): 639-48. https://doi.org/10.15408/sjsbs.v7i7.15569.

Nurhayati, Yati, Ifrani Ifrani, Abdul Halim Barkatullah, and M Yasir Said. "The Issue of Copyright Infringement in 4.0 Industrial Revolution: Indonesian Case.” Jurnal Media Hukum 26, no. 2 (2019): 122-30. https://doi.org/10.18196/jmh.20190128.

Poerana, Sigar Aji. "Cara Kerja Tanda Tangan Elektronik," 2020.

_. "Legalitas Penggunaan Tanda Tangan Elektronik Oleh Notaris," 2020.

Rahardjo, Handri. Hukum Perjanjin Di Indonesia. Jakarta: Pustaka Yustisia, 2009.

Salim H.S. Hukum Kontrak: Teori Dan Teknik Penyusunan. Yogyakarta: Sinar Grafika, 2003.

Suteki, and Galang Taufani. Metodologi Penelitian Hukum (Filasafat, Teori Dan Praktik). Depok: Rajagrafindo Persada, 2018.

Wijayanti, Asri, Rizania Kharismasari, and Aditya Ayu Hakiki. "Perlindungan Hukum Bagi Pembeli Dalam Sengketa Jual Beli Online." JUSTITIA JURNAL HUKUM 1, no. 1 (July 2017): 119-30. https://doi.org/10.30651/justitia.v1i1.596. 